\title{
Imagining institutional rationality? A fictional encounter between Ian McEwan and Wolfgang Iser
}

\author{
Peter Armstrong \\ Professor Emeritus, The Management School, University of Leicester \\ Contact Details: p.armstrong@le.ac.uk
}

\begin{abstract}
Arguing that institutional rationality constitutes a meta-institution upon which the specific institutions of the capitalist social order depend, this paper explores the possibility that it might be interrogated through the imaginary worlds created by readers in their responses to literary fiction. It does so by constructing a fictive encounter between the response aesthetics of Wolfgang Iser and two novels by Ian McEwan, Saturday and Enduring Love, both of which feature institutional rationality as a core element of the 'reality' from which they are constructed.

The conclusions are somewhat negative. The problems posed to McEwan's personifications of institutional rationality, despite the author's reputation for arbitrary and sometimes macabre plotlines, are nowhere such as to call into question their understandings of the events which befall them. Nor, reading the novels as explorations of that very one-dimensionality, are readers likely to be induced into a questioning of their own understandings of the world. This is because the novels in question, like most modern literary fiction, have been produced within a tradition which reaches back to the romantic/humanist reaction to institutional rationality, and this makes it possible for readers to distance themselves from characters in which it is exemplified. Far from producing a critical Imaginary, readers who respond in this manner are likely to externalize any interrogations of institutional rationality suggested by its fictional recontextualization and produce, instead, one in which the superiority of their own understandings of the world is confirmed. Whilst this may be opposed to institutional rationality in the routinised sense of an antagonistic accommodation, nothing new is added by the reading of the novels.

Whilst some of the problem may lie in the characterization of the principle protagonists in the selected novels - which is both flat and static, it is suggested that there is also a problem with the initial expectation of a critical imaginary created by Iser's theory. The fact is that its creation depends on an assumed response on the part of the reader which has no evidential basis. This empirical deficit cannot be made good either by Iser's earlier construct of an 'implied reader', nor by his later posit of self-aware role-taking as a fundamental anthropological need. Whilst one cannot rule out the possibility that some readers might respond as Iser supposes - even to the novels discussed in this paper - there is no particular reason to rule it in either.
\end{abstract}


Acknowledgements. The author would like to thank the helpful comments of Simon Lilley and two anonymous referees, who are jointly responsible for the considerable difference between this paper and the first draft.

\section{Institutional Rationality as a Meta-Institution}

From the late $19^{\text {th }}$ Century onwards, the advanced capitalist economies saw a vast expansion of white collar, managerial and professional occupations of all kinds. Within these strata, there came to predominate a way of thinking which Gouldner (1976) called 'technocratic consciousness'. The raw material on which this form of rationality operates is not a comprehension of the world which is itself subject to rational examination, but one which, to a first approximation, is institutionally given. This truncated conception of rationality stops short of questioning both the ends to which rational action is directed and the categories with which it operates; it is concerned only with the internal cohesion of means ${ }^{1}$. As Gouldner pointed out, the cultivation of this technocratic mindset within appropriately designed institutions has been fundamental to the evolution of capitalist economies, enabling their ruling strata to maintain outline control in the absence of ideological hegemony and where scale and complexity have made detailed intervention impossible. Otherwise expressed, it is technocratic consciousness which makes it possible for system integration to substitute for social integration (Lockwood 1964), and this is because it allows the capabilities of highly effective bureaucracies to be steered by a few political or managerial appointees at the senior levels.

A case of particular interest is that of the of the human sciences as these have been described by Baritz (1960) and, more inclusively, by Foucault (1979). Concerned with the production of amenable populations, both within the capitalist enterprise and the civil institutions which service it, these sciences, to prefer the terminology of Foucault, constitute disciplinary regimes wherein the application of knowledge is inseparable from the power relationship between the practitioner and the human material on which it is practiced (power-knowledge). In operation, they create regimes of truth in which the human subject is comprehended in terms of some institutionally defined norm (gridding practices), and on that basis is subjected to procedures rationally designed to inculcate this norm ('docile bodies'). Whilst Foucault's formulations of these ideas can reasonably be accused of over-generalizing the characteristics of total institutions (Goffman 1968) and of underplaying the hermeneutic elements in some approaches to the human sciences (e.g. Laing 1960), they nevertheless express an important insight: that the rationality of the human sciences is necessarily grounded in institutional practice, the necessity arising because the categories through which they apprehend their human subjects are not given in nature. In philosophical parlance, the terms of the human sciences are not 'natural kinds' and they must therefore be sustained by a social consensus.

The example of the human sciences further suggests that the same is true of institutional rationality in general. What substitutes for substantive rationality in its grasp of the object is firstly the institution

\footnotetext{
${ }^{1}$ Readers may well expect the discussion to invoke Weber's distinction between formal and substantive rationality at this point. It does not do so because the meaning of the distinction, and indeed the extent to which it is maintained, varies within Weber's writings (Eisner 1978). For the purpose in hand, it seems preferable to concentrate attention on the scope of rational examination, the limits placed on its application.
} 
itself, its norms, its routines and, in particular, its language and, secondly its directorate, the ruling stratum which directs its inbuilt capabilities towards particular ends. In his discussion of anti-Semitism, Adorno $(1997,200-8)$ described this externalization of the premises of rationality as 'the ticket', but his diagnosis of the syndrome applies more generally.

Thus described, institutional rationality is an extremely widespread though not universal cast of mind. Broadly speaking, it is particular to the strata which have variously been described as the cadres (Gurvitch 1971), the new petty bourgeoisie (Poulantzas 1978), the professional-managerial class (Ehrenreich and Ehrenreich 1979) or, in less politically aware formulations, the knowledge-worker (Drucker 1966), the symbol analysts (Reich 1991), and so on. Beyond this ill-defined but nevertheless real boundary is the other of institutional rationality: that which challenges or fails to recognise either the applicability of its procedures, its taken-for-granted grasp of the subject, or both. At the intellectual level - or quasi-intellectual as it would no doubt be described from the standpoint of institutional rationality - there are various religious fundamentalisms, cults and counter cultures which explicitly declare themselves against an anathema which tends to be described with a sweeping disregard for internal differentiation: 'western decadence', 'western thought', 'modernity' and so forth. At the behavioural level, there are various forms of 'mindless' improvidence, irrationalism and disruption which, once they have been identified and tagged by institutional rationality, become the subject of entirely rational moral panics amongst the 'responsible' majority (responsible in terms of institutional rationality, that is). At the level of populations, these irrationalisms are principally embodied in an educationally excluded and so largely disaffected manual working class, and, beyond them, in a lumpenproletariat which some social analysts are ominously beginning to describe as 'surplus population' (Bauman 1998). Depending on the currents of intellectual fashion, these two major categories may be topped off by a sprinkling of middle-class dropouts, a proportion of whom may later turn out to have been irrationality tourists rather than authentic misfits. In some respects, in fact, it is the existence of these human embodiments of irrationalism which provides the rationales for Foucault's human sciences, more particularly those of social work, education and criminology.

The rise of institutional rationality did not of course go unmarked and nor was it unopposed. The first and principle counter-movement was $19^{\text {th }}$ Century romanticism with its stress on the sovereignty of emotion, its yearning for untutored simplicity and its disdain for utilitarian calculation. Even today the long hangover of this reaction is probably the major source of the self-image of the self-styled creative occupations with their characteristic valorisation of expressive individualism and dissent from orthodoxy, as mythologized in a clichéd narrative of consuming vision pursued in the face of public indifference. Against this, it could be argued that this is nothing more than an ideology which conceals the diffusion of institutional rationality into the hidden abode of artistic production itself. This is most obviously the case with the industrialised production of popular fiction, popular music and departmentstore art. Even discounting these obvious cases, what may look like artistic autonomy from the standpoint of the individual producer looks like a variant of the putting-out system from the point of view of those who control the channels of marketing, the publishing houses, the record labels and the art galleries. Set against this highly rationalized machinery of cultural marketing, Adorno's faith in 
'autonomous art' as a demonstration of the possibility of escape from 'identity thinking' $(1973,22)$ looks decidedly forlorn.

Since this essay is concerned with the manner in which institutional rationality appears in 'serious' fiction - the kind of writing which is reviewed in quality newspapers, discussed in book groups and forcibly decoded by students - it is worth devoting a little more attention to the apparent opposition between the literary sensibility and institutional rationality. Following I. A. Richards $(1960,202)$, much of the case against the industrialized production of literature for a mass reading public centred on its cultivation of the 'stock response' - a deadening depersonalization of the individual's critical faculties so that their emotional responses could be tapped by the publicly-available cliché. In an attempt to combat this pernicious influence, the influential literary critic F.R. Leavis, in collaboration with one of his students, Denys Thompson, produced Culture and Environment (1933), a workbook through which several generations of sixth form students learnt to excoriate the whole apparatus of what the writers called 'Technologico-Benthamite Civilization'. The ironic result was simply another stock response in which the literary and artistic was unreflectively seen as opposed to all things scientific, technological and rationally-planned. Through the labours of its zealots, the Leavisite literary criticism which dominated the teaching of English literature from the 1930s to the 1960s, itself hardened into a form of institutional rationality with its formulaic approach to its material and its standardized machinery of judgment (Wain 1960, 175-6). That the clichéd opposition between the industrial and the literary still has currency is evidenced by the reprise of the 1959-1962 'Two Cultures' debate in David Lodge's novel Nice Work (Snow 1959; Leavis 1962; Lodge, 1989). Teaching students to 'think for themselves' on the Leavis-Thompson model, it appears, cannot so easily escape the rationality of the institutions in which that teaching takes place.

Nor, it follows more generally, can it be assumed that the opposition to a particular form of institutional rationality constitutes opposition to institutional rationality as such. Since institutional rationality is defined by an arbitrariness of its conceptual bases of action, there is no reason to expect it to be internally consistent. If as David Hume maintained, reason is the slave of the passions $(1978,415)$, it may well be enslaved by those passions which erupt from time to time in opposition to a particular form of institutional rationality and which may themselves become the doxae (Bourdieu, 1977, 164) of a new institutional rationality as they become stabilized as an orthodoxy.

\section{Re-Imagining Institutional Rationality}

If institutional rationality can be thus imagined by social theory, as an insidious dominance draining its subjects of both the will and the capacity for autonomous action, what are the prospects for imagining it otherwise, as contingent, as depending on moment-by-moment instantiation and for envisioning these instantiations as dependent in turn on a willing suspension of the capacity for independent action? One answer to questions of this kind was proposed by Willener (1970) in the course of an ad-hoc study of the Paris events of May 1968, or rather it was proposed by the students and workers and documented by Willener. From the fusion of debate and disruptive action against the existing institutional order, there emerged an 'action image of society', a new 'consciousness of the possible' (ibid 294, italics in original) enacted in the improvisation of newly-imagined social forms. (ibid 286-298). One prominent influence on the activists of 1968 was Cornelius Castoriadis $(1987,1997)$ whose work consistently stressed the 
imaginary dimension of social institutions. To Castoriadis $(1987,117,127,141 ; 1997,7-14)$ the primary experience of a social institution is through a system of symbols which refer to an imaginary dimension of meaning which suggests, guides or compels forms of action which perpetuate the institution. The creation of a new institutional form, therefore, depends on the creation of a new symbol system, through which the meaning of the old order is undermined and the new institution is stabilized:

History is impossible and inconceivable outside of the productive or creative imagination, outside of what we have called the radical imaginary as this is manifested indissolubly in both historical doing and in the constitution, before any explicit rationality, of a universe of significations $(1987,146$, italics in original)

According to Habermas $(1987,332)$, what is omitted from this emphasis on creativity is a complementary theory of how these re-imaginings, which necessarily originate with the individual, might come to be established as intersubjectively valid and so act as a focal point for social action. This objection may well be met by Castoriadis' insistence on that it is a social imaginary which is in question $(1997,8)$ implying that it is already defined by a degree of intersubjective validity. Even so, it is worthwhile exploring the possibility that a radical imaginary might emerge from another domain which is already public: that of literary fiction. That fiction of this kind works by inviting the reader to create an Imaginary in which their taken-for-granted views of the world are called into question lies at the heart of the reception theory developed over several decades by Wolfgang Iser $(1978,1993)$.

Fundamental to Iser's thinking is the idea that the reading of fiction is not an act of interpretation whether of the author's intentions (Hirsch 1967) or of a meaning to be discovered within the text itself (Wimsatt 1954). Instead, reading is conceived of as an active process through which elements of reality ordered within a fiction invite the creation of a third order of ideation which he calls the 'Imaginary'. It is the triadic relationship between the real, the fictive and the imaginary which, for Iser, defines the response to literary fiction.

First, the real: if it is to be intelligible at all, a work of fiction must work with elements of reality which Iser calls its 'repertoire'. This 'reality' though, is not that of primary sensation but that of the symbolic forms, specifically those of language, through which reality is grasped. The distinguishing feature of fictional writing, as opposed to that which aspires to be taken literally, is that these linguistic forms are detached from their normal contexts of validity and re-organized as 'instructions for the building of a situation and so for the production of an imaginary object' (Iser 1978, 64). Thus re-contextualized the forms of language through which we apprehend reality themselves become objects of scrutiny. As approached through the medium of fiction, therefore, the Imaginary is inherently disruptive and critical, having something in common with the formalist notion of defamiliarization, albeit in a more directed version. As Iser puts it, 'If the basic reference of the text is to the penumbra of excluded possibilities, one might say that the borderlines of existing systems are the starting point of the literary text.' (ibid, 72)

And again: 
Herein lies the unique relationship between the literary text and 'reality', in the form of thoughtsystems or models of reality. The text does not copy these, and it does not deviate from them either ... Instead, it represents a reaction to the thought systems which it has chosen and incorporated into its own repertoire. This reaction is triggered by the system's limited ability to cope with the multifariousness of reality, thus drawing attention to its deficiencies. (ibid, 72).

Despite the very different circumstances of their production, the one in the contemplative act of reading and the other in the noise of public disputation, it will be apparent that there is a substantial overlap between Iser's and Castoriadis' conception of the Imaginary. To Castoriadis, Iser's 'real elements' are already imaginary, bearing in mind that for the literary theorist the 'real' always refers to the languageforms through which reality is grasped. Iser's 'imaginary', meanwhile - the ideation created by the reader in response to a literary fiction - could, if Iser is correct in his attribution of a critical potential (Iser, 1978, 74), correspond to Castoriadis' 'radical imaginary'.

As preliminary exploration of the potential of literary fiction for the re-imagination of institutional rationality, therefore, this paper examines two novels in which it forms a prominent feature of the repertoire, Ian McEwan's Saturday and Enduring Love. That this is a reasonable reading of both novels is evidenced by Tim Adams' review of Saturday in the Observer (2005) and a 1998 interview on Enduring Love which McEwan gave to the online magazine Salon:

Of Saturday: 'One strand of the book's many arguments explores this debate between rationality and imagination. For all the author's occasionally irritating in-jokes, it is not clear which side comes out on top (Adams 2005).

Of Enduring Love: Interviewer: There's a real tension, in "Enduring Love," between rationality and religious belief. The protagonist, Joe, is a science writer and a professional sceptic. He's pursued, almost romantically, by a man who is religiously obsessed. At one point a character says, "Rationality is its own kind of innocence." I'm wondering what you mean by that.

McEwan: Oh, Clarissa [Joe's girlfriend] says that. There's a certain kind of insight that she feels he's missing by sticking too closely to a method. With his organized mind he can take things too literally. There is something about Clarissa's take on the world that Joe badly needs. But I wrote the book in a spirit of investigation, rather than try to give a lot of answers to either how people should live or whether one could live a good life by scientific method (Garner 1998).

\section{Two Novels by Ian McEwan}

\section{Saturday}

Saturday is a kind of day-in-the-life of middle class smug, telling of a 24 hours in the life of Henry Perowne, a successful neurosurgeon. As the novel opens, Perowne is standing at the window of his Fitzrovia residence when he sees an airliner coming in to land with one wing on fire. Since he is himself a frequent flyer, this prompts him to muse on the fragility of his ordered way of life and the forces of irrationality which might threaten it: 'A man of sound faith with a bomb in the heel of his shoe' as Perowne/McEwan puts it (17 - all page numbers in this section refer to the 2006 Vintage Paperback 
Edition of Saturday). The moment passes however, and we are back to Perowne's contemplation of Henry Perowne himself, his life and work.

Though the novel is set on the day of the massive London demonstration against the 2003 invasion of Iraq, the only real threat to Perowne's amply-documented complacency - and thus the only real source of tension in the novel - begins much later in the day when his silver Mercedes S500 takes the offside wing mirror off a red BMW which is pulling away from the curb. Silver Mercedes against red BMW: McEwan's description of the three occupants taps into other elements of the iconography of contemporary moral panic. The three have just emerged from a lap-dancing club. Two of them, Nigel and Nark, are wearing trainers and hooded track tops, 'the currency of the street' (85). Their leader is Baxter - in the exchange with Perowne he doesn't offer his forename and we never learn it. He is squat, almost a foot shorter than Perowne, dark and muscular. As described by McEwan, as perceived by Perowne, 'He's a fidgety, small-faced young man with thick eyebrows and dark brown hair razored close to the skull. The mouth is set bulbously with the smoothly shaved shadow of a strong beard adding to the effect of a muzzle. The general simian air is compounded by sloping shoulders, and the built-up trapezoids suggest time in the gym, compensating for his height perhaps' (87-8). Just in case there is any residuum of doubt, 'He gives an impression of fretful impatience, of destructive energy waiting to be released. He may be about to lash out' (ibid).

As a result of the collision, Perowne finds himself 'cast in a role': 'Here are the cars and here are the owners. Here are the guys whose self respect is on the line. Someone is going to have to impose his will and win, and the other is going to have to give way' (86). The fact of confrontation established, matters quickly escalate. Baxter demands $f 750$ cash to fix the damage with 'a mate who does bodywork on the cheap' (90). Nark and Nigel offer to march Perowne to a cash machine to get the money. Perowne counters with an offer of correct procedure: that they should exchange insurance details whereupon Baxter thumps him in the chest 'with colossal force' (92). Nigel and Nark grab Perowne by the arms and slam him against the wall. Just as it looks as if Perowne is about to get his beating, he realises that Baxter's involuntary tremors and odd eye movements add up to an indication of Huntington's chorea. Looking into Baxter's eyes, he says, 'Your father had it. Now you've got it too' (94).

This stops Baxter in his tracks. Possibly in order to conceal his condition from his companions, he orders them back into the car. Perowne presses his advantage, promising Baxter that he can get him onto the trial of a new treatment. Baxter who has already been told that his condition is hopeless, dithers over this offer, wanting to believe in it. Finally he snaps out of his indecision. Sensing that he has been cheated of his entitlement to violence, he shouts at Perowne, 'You streak of piss. You're trying to fuck with me. In front of these two' (98). He calls them back to beat up Perowne, but by then they've lost patience and give him the finger. Seizing the moment, Perowne jumps into his car and drives off, leaving Baxter fuming with rage in his rear-view mirror.

Later, Perowne is at home with his daughter Daisy, his son Theo and his father in law, John Grammaticus. Typifying the high levels of achievement which are the norm in Perowne's family, Daisy has brought along the publisher's proofs of her first book of poems, precipitating some edgy exchanges with the slightly drunk Grammaticus, also a poet, and one of some standing, They are expecting 
Perowne's wife, Rosalind a lawyer, who has had a long day in court representing the newspaper which employs her. As Rosalind opens the door to enter, Baxter and Nigel break in with her, having somehow traced Perowne to his home. Baxter is carrying a knife with which he threatens Rosalind.

Again matters escalate, though McEwan's one-dimensional prose - perhaps in mimesis of Perowne's diagnostician's sensibility - drains the scene of much of its affect and tension. Over a dozen or so pages the scene grinds as if towards a nastily predictable set piece. In a scene reminiscent of the widely reported ordeal of a clergyman's daughter who was raped in front of her family and fiancée by a gang of intruders, Baxter and Nigel force Daisy to undress. The naked but fictional Daisy, however, is spared the torment of her real-life counterpart, because it turns out she is pregnant. McEwan explains thus, 'These two young men are immature, probably without much sexual experience. Daisy's condition embarrasses them. Perhaps it disgusts them' (219).

Momentarily at a loss, Baxter's attention lights on the proof copy of Daisy's poems and commands her to read. Nigel chips in with a special request of his own, "'Let's hear your dirtiest one. Something really filthy"' (220). After some promptings from Grammaticus, Daisy pretends to read from her book, but actually recites Mathew Arnold's Dover Beach. Baxter is deeply moved and asks her to read it again. Immune to Arnold's cry of existential despair, Nigel offers to hold the knife whilst Baxter 'does the business' (222). Baxter ignores him, exclaiming over and over, 'You wrote that? It's beautiful' (ibid), the repetition possibly intended to drive home the irony of the fact that the poem isn't hers. Baxter orders Daisy to get dressed again and takes the book for himself, telling Perowne that he will try the Huntingdon's treatment after all. At this point Nigel leaves, declaring that his leader has shown himself to be 'a cunt' (223). Perowne invites Baxter upstairs on the pretext of showing him details of the treatment, at which point Theo makes a rush for Baxter. During the ensuing scuffle, Baxter falls down the stairs and is knocked unconscious. In that split second Perowne catches Baxter's eye and experiences an uncharacteristic moment of empathy:

Henry thinks he sees in the wide brown eyes a sorrowful accusation of betrayal. He, Henry Perowne, possesses so much - the work, money, status, the home, above all the family - the handsome healthy son with the strong guitarist's hands come to rescue him, the beautiful poet for a daughter, unattainable even in her nakedness, the famous father-in-law, the gifted, loving wife; and he has done nothing, given nothing to Baxter who has so little that is not wrecked by his defective gene, and who is soon to have even less. (227)

The moment passes, and Perowne, back in his default role as the eminent neurosurgeon, takes charge of the injured Baxter. The last we see of Baxter is an anaesthetized form under Perowne's scalpel as a blood clot is removed from his brain. Even as the operation is in process, Perowne is aware that in saving Baxter's life he is condemning him to the slow torture of his disease. Momentarily McEwan breaks from his reportage of Perowne's view of things in order to comment, 'Baxter heard what Henry never has, and probably never will . . Some nineteenth Century poet ... touched off in Baxter a yearning he could barely begin to define . . and was reminded of how much he wanted to live. ${ }^{2}$ (278)

\footnotetext{
${ }^{2}$ This quotation has been re-ordered in order to capture McEwan's meaning with reasonable brevity.
} 


\section{Enduring Love}

Like Henry Perowne, Joe Rose is a highly educated professional, in this case a physics graduate with a doctorate in quantum electrodynamics but now working as a science journalist. Rose lives in an art deco flat in Maida Vale with his partner, Clarissa Mellon, a university lecturer with a research specialism in Keats (whose consuming love for Fanny Brawne might be intended as a virtual benchmark against which to consider the relationships in the actual narrative). As the novel opens the pair are on their way to a picnic on the occasion of Clarissa's return from Harvard university. Before they can enjoy their day out Rose is drawn into an attempt to prevent a bizarre ballooning accident, in the course of which one of the rescuers falls to his death, a tragedy which gives rise to a second strand to the novel which is irrelevant here.

Contemplating the dead man, Rose finds himself face-to-face with Jed Parry, another of the helpers. In contrast to Rose and Clarissa, Parry's life is in some disorder. He is a former teacher of English as a Foreign Language, but is now unemployed and living alone in a large house supported by an inheritance. For Parry, the meeting with Rose is an epiphany. He immediately declares his love for Rose and begins to shadow him, convinced that every outward show of rejection is really a sign that Rose is trying to suppress his own feelings. This collision between the rational mind and its disordered other is the major axis of difference on which the novel turns. For Rose it is one susceptible of scientific classification: from his readings in popular science he is able to diagnose Parry as suffering from a homo-erotic version of de Clérambault's syndrome, on which fictitious condition McEwan's novel carries an equally fictitious appendix.

Later in the novel, Rose and Clarissa are dining out to celebrate the latter's birthday when a diner at the next table is shot in error by two masked men who have been hired by Parry to assassinate Rose. The victim is only saved from a second, fatal shooting by the intervention of Parry himself. Having failed to convince the police that the diner's rescuer was actually the instigator of the shooting, and that the intended victim was himself, Rose resolves to buy a gun with which to defend himself. This decision takes him off piste, as it were, enabling the author to stage an encounter between the scientificallytrained Rose and the kind of low-lives who might have a gun for sale. For this purpose, McEwan chooses a trio of ex-biker hippies and his chapter 21 is almost entirely taken up with his satirical portrayal of the squalor in which they live, their irrational violence and their pathetic intellectual pretension. From the point of view of the novel's plot, the episode is a digression, advancing the narrative only in the respect that Rose gets his weapon. Insofar as McEwan's theme is institutional rationality in an alien setting, on the other hand, it is entirely germane and I will return to it in a moment.

On his way back to London, Rose receives a phone call from Parry who has broken into his flat and is holding Clarissa at knife-point. When Rose enters, Parry asks Rose to forgive him for the assassination attempt and threatens to cut his own throat. Convinced that Parry still poses a threat to Clarissa, Rose shoots him, shattering the arm holding the knife. The last we hear from Parry is a letter to Rose written three years after his incarceration in a mental home. He is still in love with Rose and still convinced that his love is reciprocated. In a striking parallel with Saturday, therefore, the novel concludes with order restored, this time in the form of Parry's committal to the care of the proper authorities. 
For Rose and Clarissa, the novel ends in estrangement, partly as a consequence of the stresses they have undergone and partly because of Clarissa's suspicion that Rose was in part responsible for prolonging Parry's obsession and that he could have dealt with him more sympathetically and more effectively. Again as with Saturday, we may be intended to contemplate the defeat of Parry's irrationalism with a certain regret. There is certainly a contrast between the ease with which the relationship between Rose and Clarissa disintegrates and the enduring power of Parry's love.

The is no such emotional nuance in McEwan's contrast between Rose's scientific rationality and the loopy mysticism of his trio of hippies. As Well and Rose pick their way through a garden full of partiallydismembered motor bikes, Well explains that the occupants of the house are intellectuals 'Relative to the scene' (190 - all page references in this section are to the 1998 Vintage paperback edition of Enduring Love). By this he means, 'They got books all over the walls. They like to talk about the big questions. They think they're Bertrand Russell or something' (ibid). This draws a sarcastic comment from Rose, prompting Well to warn, 'Don't make fun of these people. They haven't had your advantages, and they're, uh, not too stable' (192).

They enter the house by the kitchen door, to find the air thick with smoke from burnt toast and the floor smeared with dog faeces. The three residents are described. Steve has a shaven head and a small waxed moustache. Xan is cleaning the floor, working the mop with 'huge forearms, hairless and meaty' (194). The woman is Daisy, whose 'long straight hair was a last rope to the bollard of her youth' (ibid). Despite their evident suspicion and dislike of Rose, the three invite him and Well to share their breakfast porridge now that the toast has been reduced to carbon.

As they sit down to eat, Steve inhales deeply through his nose with the probable intention of a brief interval of meditation. Unfortunately for Rose's resolve to avoid offending his hosts, 'Far back in some nasal cave, chance had fashioned out of mucous two-note panpipes, and we were forced to listen' (ibid). This together with the waxed moustache sets off an irresistible impulse to laugh in Rose which sends him snorting and wheezing into the garden. Well is forced to cover for him by claiming that he has an allergy.

When Rose recovers his composure, the three hosts take up the theme of allergies and it is here that we see the half-baked medicine of the counter culture through the eyes of Rose, the accredited scientist. It is Xan who begins. "'Basically", he said, looking at [Rose], "your allergy is a form of imbalance"' (196). As Rose recounts the scene, 'Xan gave his judgments the ring of fundamental truth by adorning them with "basically"' (ibid). Xan continues, "'there has to be a reason for an allergy, and research has shown that in over seventy per cent of cases the roots can be traced back basically to frustrated needs in early childhood"' (197). Rose the fictional populariser of science and McEwan the actually existing writer who makes a habit of incorporating passages from popular science into his novels, comment with one voice, 'It was a while since I had heard this device, the percentage snatched from the air, the unprovenanced research, the measurement of the immeasurable. It had a peculiar boyish ring' (ibid).

Xan's animadversions on the causation of allergies prompt Daisy to offer a contribution of her own, "There's an overriding planetary aspect with particular reference to earth signs and the tenth house", 
then Well, "It was the Industrial revolution .. when we started throwing up all this chemical shit into the air, and then into the food and water" and finally Steve, "Excuse me Johnny. But that's really a tissue of horseshit. The Industrial Revolution gave us a whole state of mind and that's where we get our illnesses" (ibid). As a comedic set-piece, the passage neatly exemplifies the combination of strengths and weaknesses which may account for some of the popularity of McEwan's work amongst the novelreading public. The writing is undoubtedly clever and might well pass for acute observation amongst some critics. What is acutely observed however, is actually a prejudicial stereotype, and one likely to be shared by many of the aforesaid readers and critics. To anticipate the argument for a moment, the Imaginary which the reader is invited to construct is one which reinforces rather than challenges that stereotype - hence the popular appeal.

Having had their fun with the pseudo science of people who 'haven't had [your] advantages' (192), i.e. the advantages of an institutionally validated scientific education, but who nevertheless had the grace to provide the mise en scéne for their own humiliation by sharing their meagre breakfast, McEwan/Rose decide that enough of this sort of thing is enough and they return to the business of the gun. Rose hands over the cash, takes the gun and we leave McEwan's hangovers from the 1960s counter culture with Xan and Steve locked in combat over the money. As Rose and Well make their escape, Xan has Steve in a life-threatening headlock but we never learn the outcome and nor, so runs the implication, should we care.

\section{Ian McEwan and the Critical Imaginary}

What, exactly, is being offered up for critical reflection in these novels? Insofar as institutional rationality is one of the major elements from which the fictions are constructed, the extent to which it is decontextualised so as to make such an examination possible seems very limited. Rather, it seems to be depicted as very much on its home ground.

Reviewing Saturday for the New Statesman, Sophie Harrison (2005), observed that Baxter is written as an implausibly ineffectual threat, even though that threat is central both to the narrative structure of McEwan's novel and to its claim to constitute a serious examination of what might trouble a man at ease in his understanding of the world. Not only is Baxter carrying a disease which just happens to lie within the area of Perowne's medical competence, he is also burdened with a latent and wholly implausible susceptibility to the verse of Mathew Arnold. Far from undermining Perowne's faith in his understanding of the world, Baxter's illness reinforces his faith in its relevance and potency, just as Daisy's faith in the numismatic power of great literature is confirmed by its capacity to induce motivational paralysis in an untutored thug.

Perhaps, though, the novel's invitation is not for the reader to identify their grasp of the world with that of Perowne but to contemplate it from the outside, for example as an exemplification of onedimensionality. This is consistent with the brief note of sympathy on which the novel ends; sympathy not only for the unfortunate Baxter stripped of his powers by Daisy's recitation and lured to his doom by the promise of a non-existent cure, but sympathy too for Henry Perowne who, for all his advantages and triumphs, would never hear what Baxter heard in the final stanza of Dover Beach. 
Insofar as the novel can be read in this manner, it points to an important possibility which is neglected in Iser's theorization of the reader's response: that the elements of 'reality' incorporated into a fiction might be seen by the reader as those of other people rather than themselves. More accurately, the raw material of the reader's imaginary might be the grasp of reality attributed by both authorial voice and reader to people who differ from themselves, and attributed moreover on what might be a conventional or stereotypical basis. That would make Saturday a celebration of the superior sensibility of the literary intellectual (assuming for the moment that the readers of the novel can be so described) as it contemplates the inferior one of the technocrat (assuming ditto for neurosurgeons). Far from a critical examination of one's grasp of the world, such an imaginary would be a rather comfortable place to spend time, Perowne's smug self assurance mirrored and even exceeded by the reader's sense of superiority to such as Perowne. That sense of superiority could be construed as a critique of institutional rationality only if the latter were narrowly identified with the character structure of the technocrat and assumed to be entirely absent from that of the literary intellectual.

Similar remarks apply to Enduring Love. To be sure Rose is challenged by the events of the novel - the ballooning accident, his stalking by Parry and even the comedic encounter with the biker-hippies, but never in a way which calls into question his grasp of what is going on. In particular Rose sees Parry's obsession unequivocally as a medical condition and never as a reproach to his own attenuated capacity for empathy. Should the novel be alternatively construed as an invitation to construct an imaginary in which it is such a reproach, on the other hand, for example on the basis of Clarissa' criticism of Rose's unsympathetic handling of Parry, or of the contrast between Parry's love (and John Keats') and their own tepid affair, it is again too easy for the reader to construct Rose as a technocrat from whom the reader can distance themselves by the very fact of their engagement with a serious work of fiction.

Given the stereotypical opposition between technocratic and literary intellectuals, this is always going to be a difficulty with the treatment of institutional rationality in a work of fiction. Even those readers whose working lives involve a technocrat's view of the world, can engage with fictions through an alternate identity as self-imagined polymaths, thereby exempting themselves from the critical examination of the world view which is implied.

As far as the individual is concerned, the problem with institutional rationality might be conceived as twofold: that it is a form of 'identity thinking' (Adorno 1990, 149) in which the real is truncated by the language-forms through which it is grasped and that it is a kind of alienation (or inauthenticity) in that the identity thinking involved is not even the subject's own. If literary fiction is to engender a new consciousness of these problems (as opposed to a mere restatement of them) it needs to provide the reader with the materials to construct an imaginary in which both institutional rationality and its deformations are simultaneously experienced. That cannot be achieved simply by having one character criticise the overly-rational understandings of another (Enduring Love) nor by encouraging the reader to do the same (Saturday?), because particularizing institutional rationality in this manner is itself a form of identity thinking which reduces it to a question of character. The problem faced by literary fiction in avoiding this reduction, and the consequent evasion of self-confrontation on the part of the reader, is that its own very existence as an institution tends to posit a sensibility which believes itself to transcend institutional rationality. 
It may be that a more insightful writer than lan McEwan might have found some means of disrupting this complacent response. That McEwan himself can be read without any such inconvenience might account for the fact that he outsells most other 'serious' UK novelists by a considerable margin. Publisher's Weekly reported sales of 207,096 copies of Saturday in 2005 (Maryles 2006) a figure comparable to those of popular crime writers such as Robert Parker and P.D. James.

This may mean that McEwan is not a good test of the capacity of literary fiction to set in motion a critique of institutional rationality or even that his work cannot be taken as a serious invitation to construct an imaginary in Iser's sense. Might it belong, perhaps, with 'the mounds of light literature which flow regularly into the pulping machines' because they permit 'a total consumption of the text' without ever calling for an act of imagination on the part of the reader (Iser 1978, 29)? Or perhaps it is to be classed with that slightly less pernicious genre which endorses rather than challenges 'prevailing systems' and is, in consequence, 'often ... of a more trivial nature' (ibid, 77)? Whilst such assessments are certainly arguable, they place the dissenter at odds with both a mass of critical opinion and a considerable public which believes itself to be engaged with a major novelist. As of February 2009, McEwan's work has won eleven major literary awards including the James Tait Black Memorial Prize for Saturday ${ }^{3}$. It has also inspired fifteen volumes of criticism, three of which concentrate exclusively on Enduring Love, two of which are guides for sixth form students and one of which is McEwan's own reader's guide to Atonement. ${ }^{4}$

\footnotetext{
${ }^{3}$ As of $3^{\text {rd }}$ March 2009, Ian McEwan's website (http://www.ianmcewan.com/) was headed by the following declaration:

McEwan's works have earned him worldwide critical acclaim. He won the Somerset Maugham Award in 1976 for his first collection of short stories First Love, Last Rites; the Whitbread Novel Award (1987) and the Prix Fémina Etranger (1993) for The Child in Time; and Germany's Shakespeare Prize in 1999. He has been shortlisted for the Man Booker Prize for Fiction numerous times, winning the award for Amsterdam in 1998. His novel Atonement received the WH Smith Literary Award (2002), National Book Critics' Circle Fiction Award (2003), Los Angeles Times Prize for Fiction (2003), and the Santiago Prize for the European Novel (2004). He was awarded a CBE in 2000. In 2006, he won the James Tait Black Memorial Prize for his novel Saturday and his novel On Chesil Beach was named Galaxy Book of the Year at the 2008 British Book Awards where McEwan was also named Reader's Digest Author of the Year.

${ }^{4}$ As listed on Ian McEwan's website the critical texts are:

David Malcolm, Understanding Ian McEwan, University of South Carolina, 2002.

Peter Childs. The Fiction of Ian McEwan . (Readers' Guides to Essential Criticism) . Palgrave Macmillan, 2005.

Jack Slay, Jr. Ian McEwan (Twayne's English Authors Series) Twayne Publishers, 1996.

Kiernan Ryan. Ian McEwan (Writers and Their Work) . Northcote House, 1994

Peter Childs. Ian McEwan's "Enduring Love" . (Routledge Guides to Literature). Routledge, 2006

Margaret Reynolds \& Jonathan Noakes. Ian McEwan: The Essential Guide. (Vintage Living Texts). Vintage, 2002 Ian McEwan. Atonement (Reading Guide Edition). Vintage, 2005.

Anne Rooney . York Notes on "Atonement" . (York Notes Advanced) . Longman / Prentice Hall, 2006. Robert Swan, editor. AS/A-level English Literature: "Atonement". Philip Allan Updates, 2006 Roger Clarke \& Andy Gordon. Ian McEwan's Enduring Love: A Reader's Guide. Continuum Pub Group, July 2003 Jane Gibson. A Level Notes for lan McEwans Enduring Love. Cotton \& Jarrett, December 2003.

Bernie C. Byrnes. The Work of Ian McEwan: A Psychodynamic Approach. Pauper Press, 2002

Bernie C. Byrnes. Ian McEwan's Atonement \& Saturday: A Supplement to The Work of Ian McEwan: A Psychodynamic Approach. Paupers' Press, 2006
} 
Or perhaps there is something wrong with Iser's theory.

\section{Conclusion: Iser's Imaginary Reconsidered}

It will be apparent that Iser's view of the Imaginary as a critical apprehension of one's grasp of reality, including that of institutions, hinges on a particular view of the reader's response to the literary text. As Iser himself pointed out, it is a view which lacks empirical verification (Iser 1978, x), and it continued to do so throughout his career. In The Act of Reading, he attempted to finesse this difficulty by positing an implied reader, by which he meant a role which the real reader is offered by the text (ibid, 34). The problem here is that the implied reader is itself a reading of the text and probably one by a literary critic. Besides this, Iser's emphasis on reading as an act of creation, required him to acknowledge that, 'the [implied] reader's role can be fulfilled in different ways, according to historical and individual circumstances' (ibid, 37). Iser himself rendered this variation as 'a selective realization of the implied reader' (italics added), but what if the [real] reader's response to the text is not so much a selection from that of the [critic's] implied reader, but a flat contradiction of it? All that is left at this point is either an acknowledgment of the empirical deficit or an assertion of critical authority, neither of which seem much of a basis on which to deny the legitimacy of a [real] reader's evasion of the challenge to construct a self-critical imaginary.

By the time of The Fictive and the Imaginary (1993), Iser's attention had shifted to the question of why the production and consumption of fictions appeared to be a cultural universal. Correspondingly the empirical deficit was now made good by means of a philosophical anthropology, a theory that fiction fulfils a fundamental human need. Appropriately enough for a theory of fictions Iser built up this thesis through a lengthy meditation on the pastorale which, he claimed, was the dominant literary form for fifteen hundred years ${ }^{5}$.

From its beginnings in classical antiquity, said Iser, the pastorale invited the construction of an imaginary. Ostensibly about shepherds, it was actually 'poetry written by poets about poets, though these poets enact themselves as shepherds so that, in the guise of simple people, they can explore the imaginative possibilities of poetry's acting on the ordinary socio-political world.' (Iser 1993, 31-2). As the form developed, the shepherds accumulated additional and sometimes surprising capabilities. They took to voicing political concerns quite alien to those of simple herdsmen and to pursuing their ends by donning masks to which were attached the particular powers defined by a hierarchical social order: those of princes, poets or priests. In this strategic assumption of alternate identities, Iser saw a fictive enactment of the division which is characteristic of human beings: a 'doubling' in which 'Roles are not

Bernie C. Byrnes. McEwan's Only Childhood: Development of a Metaplot. Paupers' Press, 2008

Claudia Schemberg. Achieving 'At-one-ment'. Storytelling and the Concept of the Self in Ian McEwan's The Child in Time, Black Dogs, Enduring Love, and Atonement. Peter Lang, 2004.

${ }^{5}$ In view of the learning on display in Iser's exposition, and the praise due to an attempt to find firm ground for his argument in a concrete literary tradition, it seems churlish to observe that his account of this fifteen hundred year dominance is actually an account of a fifteen hundred year gap: that between the pastorales of Virgil and those of Edmund Spenser. Besides which, there is the question of what the 'dominance' of a literary form might mean in the context of an anthropological thesis, given the paucity of literacy and its concentration in the religious orders during the intervening centuries. Amongst whom was the pastorale dominant as a literary form? 
disguises with which to fulfil pragmatic ends; they are means of enabling the self to be other than each individual role' (ibid, 81). Because 'The state of being above and outside oneself is not merely a transitory phase but is a fundamental characteristic of humanity' (ibid, 84), Iser could now conclude that the creation and consumption of fictions does indeed fulfil a fundamental anthropological need ${ }^{6}$.

So too, unfortunately for Iser's argument, does the formation of the generalised other in the normal course of social life, through the sedimentation of repeated acts of taking the role of significant others (Mead 1934). Iser, however, wanted to argue for a unique 'advantage of literary fictionality' (Iser 1993, 82). His exposition at this point is obscure, at least in translation, but he appeared to find it in the nature of fictionality itself: that the specific form of doubling which it calls for 'discloses itself as pure semblance; in other words, inscribed into the modes of representation is the denial of any correspondence to anything existing'. This appears to mean that the act of taking on a role for the unadulterated experience of observing oneself in the act of doing so offers a unique insight into the human condition.

The argument is pitched at a level of exaltation which makes the mundane questions which need to be asked of it appear gauche indeed. To ask them nevertheless: children's games, would appear to possess all of the characteristics of literary fiction which bear on Iser's argument and this would suggest not only that that they share its 'unique' virtues, but that they substitute for them in most cases. The second question is the obstinate one of empirical confirmation, now displaced from the question of what literary fiction does to that of that of whether it does what Iser's speculative anthropology now claims for it. Specifically, if the consumption of literary fiction in the manner which Iser recommended fulfils a fundamental anthropological need, we should be able to distinguish those individuals in whom that need is fulfilled from those in whom it is not - and how is it proposed that we might do that?

From all this it follows that Iser's reception theory guarantees nothing about how real readers respond to the literary text. It has been suggested earlier that this is particularly important in the case of institutional rationality. Where this is present as an element in the repertoire of a literary fiction there are particular incentives and opportunities for the reader to evade Iser's prescriptions and to construct instead an imaginary which fails to recognise and confront their own implication in it. Where this is the case the imaginary which Iser hoped would subvert the reader's taken for granted symbolic representations of the of the world, may turn out instead to be a smug celebration and confirmation of

\footnotetext{
${ }^{6}$ There might not seem to be much connection between the 'elements of reality' discussed in The Act of Reading (1978) and the 'role-taking' of The Fictive and the Imaginary (1993), but there is more than at first appears. The connection, appropriately enough is through language. In a literary text, as in the writings of a literary theorist, 'reality' refers always to a discourse about reality just as 'role' refers to a discourse through which a role is represented. Since the latter is jointly represented by a discourse about reality from the point of view of the role and a discourse about the role and its associated representations from other points of view (including that of the narrator and the authorial voice) the 'elements' and the 'roles' tend to converge in practice. The difference is that in the later publication the act of imagination is turned inwards, becoming a contemplation of the human condition as such: 'The fictional ecstasy permits us to step outside the contexts that normally define what we are.' (Iser 1993, 84). Whilst this may be appropriate enough in a quest is for anthropological fundamentals, its implications for the critique of institutions are quietist. The re-imagining of institutions, insofar as it occurs at all in the Iser of 1993, is incidental to a re-imagining of the self.
} 
them, all the more self-congratulatory through the contrast with a benighted other. Thus Iser's imaginary and that of Castoriadis diverge once more, not because Iser's is conservative in principle, but because it is too open to the possibility of turning out to be so in the case of institutional rationality, and because institutional rationality is the generic form which needs to be subverted if social change is to be on the agenda.

For all that, Iser's failings are generous ones. People who love literature - as Iser so clearly does - are like other lovers in their tendency to attribute to the object of their love what properly belongs to the love itself, the attribution in this case being one of profound critical significance. As Carey $(1992,74)$ remarked of Clive Bell's rhapsodies about 'dangerous journeys' into the 'cold white peaks of art' (1928) - it needs to be remembered that what is at issue is actually looking at pictures or reading books, and that both can be done without putting much at risk.

\section{References}

Adams, Tim (2005) When Saturday comes lan McEwan's dazzling novel takes just a single day to explore society itself, but this is a Saturday like no other, says Tim Adams. The Observer, Sunday 30 January. [http://www.guardian.co.uk/books/2005/jan/30/fiction.bookerprize2005] Last Accessed 2/3/09.

Adorno, Theodor W. (1990) Negative dialectics. Trans. E.B. Ashton. London: Routledge.

Adorno, Theodor W. and Max Horkheimer (1997) Dialectic of enlightenment. Trans. John Cumming. London: Verso.

Adorno, Theodor W. (1973) Philosophy of modern music. Trans. Anne G. Mitchell and Wesley V. Blomster. New York: The Seabury Press.

Baritz, Leon (1960) The servants of power. New York: Wiley.

Bauman, Zygmunt (1998) Work, consumerism and the new poor. Buckingham: Open University Press.

Bell, Clive (1928) Civilization: an essay. London: Chatto and Windus

Bourdieu, Pierre (1977) Outline of a theory of practice. Trans Richard Nice. Cambridge: Cambridge University Press.

Castoriadis, Cornelius (1987) The imaginary institution of society. Trans. Kathleen Blamey. Cambridge. Polity Press.

Castoriadis, Cornelius (1997) World in fragments: Writings on politics, society, psychoanalysis and the imagination. Trans. David Ames Curtis. Stanford Ca.: Stanford University Press.

Drucker, Peter F. (1966) The effective executive. New York: Harper-Collins.

Ehrenreich, Barbara and John Ehrenreich (1971) The professional-managerial class. Radical America 11, 2. 
Eisen, Arnold (1978) The meanings and confusions of Weberian rationality. British Journal of Sociology 29, 1: 57-70.

Foucault, Michel (1977) Discipline and punish: the birth of the prison. London: Allen Lane.

Garner, Dwight (1998) The Salon Interview - lan McEwan: Dwight Garner talks to lan McEwan, the black magician of contemporary fiction, about mortality, gossip and his arresting new novel, 'Enduring Love.' [http://dir.salon.com/story/books/int/1998/03/31/cov si 31int/ ] Last Accessed 2/3/09.

Goffman, Erving (1968) On the characteristics of total institutions. In Asylums: essays on the social situation of mental patients and other inmates, 13-116.,Harmondsworth: Penguin.

Gouldner, Alvin W. (1976) The dialectic of ideology and technology : the origins, grammar and future of ideology. London. Macmillan.

Gurvitch, Georges (1971) The social frameworks of knowledge. Trans. Margaret A. Thompson and Kenneth A. Thompson. Oxford : Blackwell.

Habermas, Jurgen, (1987) The philosophical discourse of modernity: twelve lectures. Trans. Frederick Lawrence. Cambridge: Polity Press.

Harrison, Sophie (2005) Happy Families. New Statesman, $24^{\text {th }}$ January, 48-49. This and a vast range of other material relating to McEwan's work is accessible at http://www.ianmcewan.com/. Last accessed $3^{\text {rd }}$ March 2009.

Hirsch, Eric D. (1967) Validity in interpretation. New Haven: Yale University Press.

Hume David (1978) [1739-40] A treatise of human nature. Ed. L.A. Selby-Bigge. Oxford: Clarendon Press. Iser, Wolfgang (1978) The act of reading: a theory of aesthetic response. Baltimore: John Hopkins University Press.

Iser, Wolfgang (1993) The fictive and the Imaginary: charting literary anthropology. Baltimore: John Hopkins University Press.

Laing, Ronald D. (1960) The divided self : an existential study in sanity and madness. London: Tavistock Publications.

Leavis, Frank R. and Denys Thompson (1933) Culture and environment : the training of critical awareness. London: Chatto and Windus.

Lockwood, David (1964) Social integration and system integration. in George K. Zollschan and Walter Hirsch (eds.) Exploratios in social change. London: Routledge and Kegan Paul.

Lodge, David (1989) Nice work. London. Penguin. 
Maryles, Daisy (2006) While veteran novelists and celebrities dominate, a few newcomers shine. Publishers Weekly, 27 ${ }^{\text {th }}$ March 2006, http://www.publishersweekly.com/article/CA6318930.html 27/2/09. Last accessed 28/2/08

McEwan, lan (1998) Enduring love. London: Vintage.

McEwan, Ian (2006) Saturday. London: Vintage.

Mead, George H. (1934) Mind, self, and society : from the standpoint of a social behaviorist. Chicago: University of Chicago Press,

Poulantzas, Nicos (1978) Classes in Contemporary Capitalism. London: Verso.

Reich, Robert B. (1991) The work of nations : preparing ourselves for $21^{\text {st }}$ century capitalism. London: Simon and Schuster

Richards, lan A. (1960) Principles of literary criticism. London: Routledge.

Snow, Charles P. (1959) The two cultures and the scientific revolution : the Rede lecture. Cambridge: Cambridge University Press.

Wain, John (1962) Sprightly running : part of an autobiography. London: Macmillan.

Willener, Alfred. (1970) The action-image of society: on cultural politicization. Trans. A.M. Sheridan Smith. London: Tavistock.

Wimsatt, William K. (1954) The verbal icon : studies in the meaning of poetry / and two preliminary essays written in collaboration with Monroe C. Beardsley. Lexington: University of Kentucky Press. 